\title{
The Credit Asset of Enterprise Accounts Receivable Pricing Model
}

\author{
Deshun $\mathrm{Xu}^{1,2}$ and Junhai Ma $\mathbb{D}^{1}$ \\ ${ }^{1}$ College of Management and Economics, Tianjin University, Tianjin 300072, China \\ ${ }^{2}$ Chinese Academy of International Trade and Economic Cooperation, Ministry of Commerce, Beijing 100710, China
}

Correspondence should be addressed to Junhai Ma; mjhtju@aliyun.com

Received 1 February 2018; Revised 30 July 2018; Accepted 7 August 2018; Published 8 October 2018

Academic Editor: Dan Selişteanu

Copyright (c) 2018 Deshun $\mathrm{Xu}$ and Junhai Ma. This is an open access article distributed under the Creative Commons Attribution License, which permits unrestricted use, distribution, and reproduction in any medium, provided the original work is properly cited.

\begin{abstract}
Based on the thinking of holism and reductionism, this paper creatively constructed the credit asset pricing model of enterprises' accounts receivable, namely, the BEST pricing model, and it was demonstrated effectively. The model gave an overall evaluation on the default probability of buyer and environment, as well as buyer loss given default resulting from the factors including Seller (S), Buyer (B), and Environment (E). The model is also utilized with the optimal control management Technology (T) to maximize the intrinsic value of the credit asset. The paper put forward the Duration of accounts receivable aging, measurement method of dynamic free interest rate, and amended the KMV model to solve the default probability of accounts receivable of listed and nonlisted companies. To evaluate the credit asset risk, the following were selected: three effective financial indicators, seven nonfinancial index clusters, and sixty-three specific nonfinancial index variables of the buyer; one index and eight specific indicators of the seller; and one index and fourteen specific indicators of nonsystematic risk of the environment. Five appropriate hedge parameters are used to control the risk.
\end{abstract}

\section{Introduction}

In this paper, the pricing method for a special credit asset, considered as a company's debt which is not due, is discussed. Recently, no authoritative definition is put forward worldwide for the conception of enterprises' credit asset, and different opinions are also discussed in China. There are mainly a couple of viewpoints well accepted in China. Some researchers treat the enterprises' credit assets as intangible assets, which are an important composition of the enterprises' intangible resources, just the same as goodwill. Another widely accepted viewpoint in China describes the enterprise credit asset as a book asset which is formed on the foundation of credit. In 1997, Zhang [1] defined credit assets as accounts receivable or notes forming where enterprise sold goods or provided services on credit, including unsecured receivable notes, receivable accounts, and other receivables. Besides, in 2015 and 2017, Xu [2, 3] thought that credit not only has economic value, but also includes the spirit of morality and legality; although it originated from the economy, credit nowadays becomes a unity of the subjective element of faith and the objective element of solvency. As an economic concept, enterprise credit assets are special assets that form based on the counterparty trust instead of physical assets, including unsecured receivable accounts, receivable notes, and other tangible credit assets. In this paper, pricing of the accounts receivable credit assets, which is basic among an enterprise's credit assets, is discussed.

The pricing of enterprise credit assets could be applied in various fields, such as improving the microfoundation of the market economy, facilitating revitalization of increasingly large commercial credit assets, easing the dilemma of financing difficulties and high costs for enterprises and oversupply of $\mathrm{M} 2$, and promoting the healthy development of supply chain finance and macroeconomics. Although accounts receivable credit assets are seldom studied in the field of pricing assets, abundant studies on credit assets including nonperforming loans provide many inspirations. On the other side, in the field of accounts receivable credit 
assets, most of the interest was concentrated on the accounting management, system establishment, and securitization; direct studies on the pricing are relatively rare.

In 2009, Zhang [4] quantitatively studied the pricing of entity enterprises' accounts receivable assets, treating the accounts receivable as creditor's rights, and taking the credit risk and redemption risk, as well as depreciation risk into consideration. In 2010, He et al. [5] analyzed the pricing of accounts receivable financing with or without the right of recourse, discussing the repurchase of accounts receivable with real options theory. They figured out the basic value of the accounts receivable by approximating the actual repayment period to the duration, and evaluating each value of accounts receivable considering repayment risk, decay with time, and loss in liquidity discount through analyzing the value structure of accounts receivable financing. In 2010, Szpulak [6] indicated that prediction for sellers' income and amortization period of the accounts receivable should be the key problems for pricing. In 2014, Zhan et al. [7] put forward a supply chain decision model which combines accounts receivable financing and mercantile credit. In 2014, Wilkens and Bethke [8] reported a pricing model for Contingent Convertible (Coco) bonds. In 2013, Wang et al. [9] supposed that improvement on the performance of accounts receivable is needed, according to the working capital data of 2299 Chinese listed companies in 2013. In 2015, Zhou et al. [10] analyzed the formation and development of the pricing model of credit risk for corporate bonds, based on the pricing model of option and theory of discounted cash flow. In 2015, Chen et al. [11] studied the efficient control methods of the Alibaba Co. for dynamic monitoring on customer default risk and antifraud control through manmachine conversation and machine learning, depending on the big data. In 2017, Bahadir and Valev [12] provided evidence for convergence in the levels of household and business credit. In 2018, Gubareva and Borges [13] developed a derivative-based integrated approach to quantify economic capital requirements on interest rate and credit risk. In 2018, Jia et al. [14] explored factors that are attractive for consumers and thereafter affect their use of ecommerce consumer credit services.

The research outcomes mentioned above offered some useful helps to us particularly in ideas and methods; however, some puzzles have not been solved, such as measuring the dynamic risk-free interest rate and the volatility on liquidating the credit assets of nonlisted companies. The contributions of this paper are mainly the following: (i) The three-dimensional view of belonging is set up coming from the buyer, seller, and environment; it provides methods for research on systematically discriminating expected and unexpected risks of receivables. (ii) By importing the effective riskavoiding parameters, it provides tools for controlling and managing credit risks of receivables. (iii) It succeeds in enriching the Macaulay duration theory by putting forward receivables duration and measurement method of dynamic risk-free interest rate. (iv) The amended KMV model can solve the default probability of receivables in nonlisted companies by forecasting the volatility on liquidating the credit assets of nonlisted companies and expanding the applied range of option pricing theory. Based on the abovementioned conclusions, expanded research from $\mathrm{Xu}$ et al. in 2018 [15-17] partly verified the credit asset pricing model of enterprises accounts receivable.

\section{Model}

2.1. Model Assumption. Intrinsic values of different enterprises' accounts receivable are complex as the result of the complexity of business. Receivables with an equal book value and account receivable age in different enterprises do not mean equal intrinsic value. Besides, different clients and environments means different risks, so receivables of an enterprise also mean different intrinsic values.

To discuss the intrinsic value of the accounts receivable credit assets about its forming and changing, the following assumptions are given to simplify the complexity:

(1) Credit grantor, the seller, is a rational homoeconomics man

(2) Credit receiver, the buyer, is a rational homoeconomics man

(3) Only accounts receivable in goods trade are studied

(4) There is no operational risk from the seller

(5) The fluctuations of the value of the seller's accounts receivable, seller's investment return, and buyer's revenue growth of assets realization follow the Brownian motion and lognormal distribution

(6) The business environment is risk-neutral, and riskfree interest rate is instability constant variable

(7) Each subsystem's independent variables makes an effect on the intermediate variable, finally having an effect on the dependent variable of the whole system; on the other hand, the intermediate variable adjusts the interaction between different subsystems' independent variables

(8) Control variables change the dependent variable by their controls on independent variables and intermediate variables

(9) The enterprise owning accounts receivable credit assets is the seller, while monetizing the assets mainly depends on the buyer; therefore, the buyer's business standing is the key point for this research

2.2. Model Mechanism. Pricing system of accounts receivable credit assets is a complex dynamic system with a selforganizing dissipation structure. Some state variables (e.g., credit amount and aging) are constant, and some other variables are common attractors under a nonequilibrium state, for example, risk-free rate under a steady state and strange attractors, such as chaos state caused by individual default variables.

In this paper, the complex problem of pricing of enterprises' accounts receivable credit assets is simplified into single accounts receivable with a debtor-creditor relationship at 


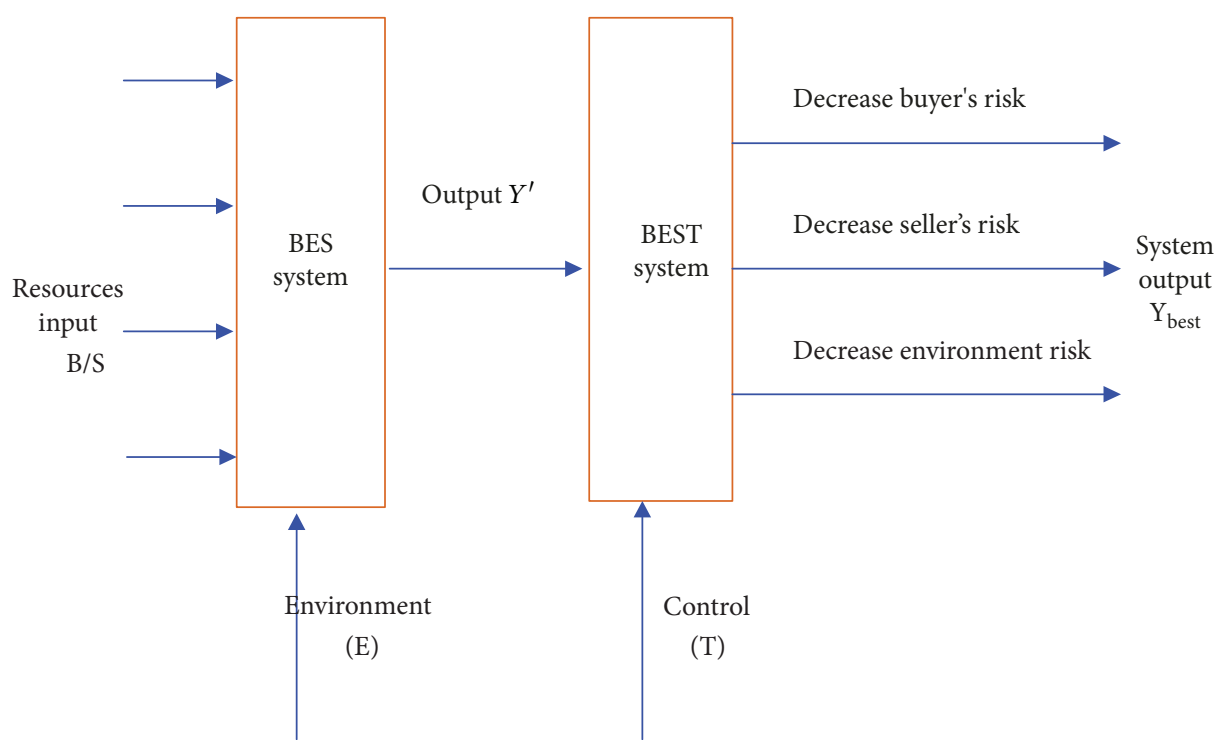

Figure 1: The mechanism of BEST control and management system.

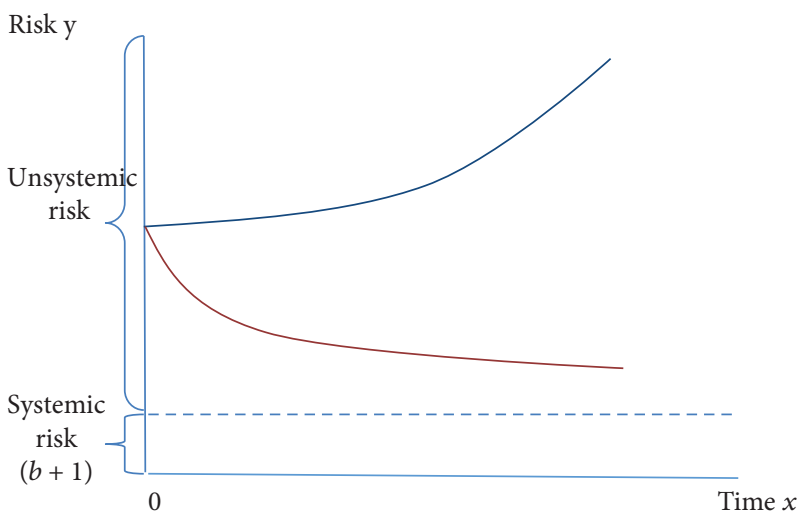

Figure 2: The relationship between credit assets and risk portfolio before and after control.

the beginning in order to make easier analysis. Then, based on the discussion of a simplified case, a complex study with two and more transactions could be analogized and exposed. As a common characteristic, each accounts receivable refers to creditors (sellers), debtors (buyers), and the relating business environment, so the pricing system for accounts receivable credit assets should also contain Buyer (B), Seller (S), and Environment (E) subsystems, with a complex interaction between factors of a subsystem, as well as interaction between subsystems. Under control and management of Technology $(\mathrm{T})$, various factors of various subsystems entangled and finally had an impact on the dependent variable, and the three subsystems including B, E, and S and the control factor $\mathrm{T}$ make up the BEST pricing system.

Before control variables were introduced into the system, factors which have an effect on the pricing show obvious randomness, even showing compliance with the Brownian movement, except for a few relatively stable factors such as the credit amount, aging, and discount rate, resulting that pricing used to be strongly uncertain. Figure 1 shows that control variables introduced through the technical side (T) optimizes BES system into BEST; the new system exhibits some positive changes as expected. The sellers, the owners of accounts receivable credit assets, strengthen the whole process control and management, in order that they offer reasonable credit towards the buyers. The buyers strengthen control and management in order to minimize the overall loss of the sellers' credit. Meanwhile, the business environment has also been changed by the trade participants' adaptive behavior for environment. Finally, the intrinsic value of the receivables from $Y^{\prime}$ to $Y_{\text {best }}$ with the BEST model, was optimized as shown in Figure 1.

Figure 2 shows the risk before and after controlling the variables. The risk time relevant before control can be treated as an increasing nonlinear monotone; namely, as time passes, the risk increases and the curve steeply increases. After control and management, the unsystemic risk decreases as the time passes and the control strength is added. Finally, it tends to 0 . Then, the risk approximates systemic risk, viz., the risktime relevant nonlinear monotone decreases.

The curve before control can be simulated as

$$
\begin{aligned}
& y=a^{x}+b, y \in[b+1, \infty), \\
& \text { s.t. }\left\{\begin{array}{l}
a>1 \\
b>0 \\
x \in[0, \infty) .
\end{array}\right.
\end{aligned}
$$

After control, the curve becomes

$$
\begin{gathered}
y=\frac{1}{\ln (1+1 / x)^{x}}+b, y \in(b+1, \infty), \\
\text { s.t. }\left\{\begin{array}{l}
b>0 \\
x \in(0, \infty),
\end{array}\right.
\end{gathered}
$$


where $y$ is risk, $x$ is time, ' $b+1$ ' is systemic risk, and $a$ is the constant. The constraint condition is related to the economic connotations of (2).

\subsection{The Nodes in Model Design}

2.3.1. The Dynamization of Expected Risk-Free Interest Risk. How to obtain a reasonable discount rate is one of the core problems. If there is neither dispute in credit sale nor risk factor between buyers and sellers, the risk does not exist in the outer environment, which is related to both sellers and buyers. The buyers fully pay their credit to the sellers in time. The mathematical model for pricing will be the easiest one, which is related to only 3 variables including credit amount, aging, and risk-free discount rate. Its mathematical expression will be

$$
E\left(Y_{i v}\right)=Y_{b v} \cdot e^{-R N}=Y_{b v} \cdot e^{-R_{f} \cdot N},
$$

where $E\left(Y_{i v}\right)$ represents intrinsic value expectation, $R$ represents annual market discount expectation, $N$ represents the number of years, $n$ is the number of days, $N=n / 365$. As what is said above, if there will not be any kind of compensation for risk taking, $R$ will be seen as risk-free rate $R_{f}$. Since the valuations and the entire market development are dynamic, the risk-free rate $R_{f}$ which can change based on time, will be dynamic. This can lead to

$$
R_{f} \cdot N=\left(\sum_{n=1}^{i} \frac{r_{f_{n}}}{n}\right) \cdot 365 \cdot\left(\frac{n}{365}\right)=\overline{r_{f_{t}}} \cdot 365 \cdot\left(\frac{n}{365}\right)=\overline{r_{f_{t}}} \cdot n .
$$

Formula (3) and (4) can lead to formula (5):

$$
E\left(Y_{i v}\right)=Y_{b v} \cdot e^{-R_{f} \cdot N}=Y_{b v} \cdot e^{-\overline{r_{f t}} \cdot n} .
$$

Formula (3) is a theoretical model. In practice, the expected risk-free rate can be forecast by history. Since accounts receivable credit asset belongs to current asset in essence, its time limit is less than 1 year in general. The current risk-free rate is derived by the average of the 30 days (20 working days) before the fixing date, while supposing that the everyday risk-free rate after the fixing day will be the same. In this model, different risk-free rates of fixing date are dynamic, but the everyday risk-free rate after the fixing date cannot be dynamic.

2.3.2. Accounts Receivable Aging. Enterprise credit assets of accounts receivable belong to a special type of enterprise credit assets, which the seller holds as the debt to the buyer, similar to the seller's reversely holding of the buyer's "invisible bond," referring to the sellers' owing bonds of the buyer with information recorded but no real object. The differences in the term have direct impact on the intrinsic value of accounts receivable $\left(Y_{i v}\right)$.

Duration (D) is a classic measure of bond risks. If the enterprise accounts do not have any overdue and default risks and the risk-free interest rate is not market oriented, theoretically, it is meaningless to introduce the concept of duration. But now interest rates including risk-free interest rates are marketed, and the daily interest rate (yield to maturity) of bonds in the duration is different, so the introduction of Duration becomes valuable, no matter for discounted bonds or zero coupons; even accounts receivable can be fully returned without expiration. For the pricing of enterprise credit asset of accounts receivable, the measurement of duration should be at any point in the period from the beginning $\left(A R_{0}\right)$ to the end $\left(A R_{T}\right)$ of accounts receivable, in order to be a more accurate measurement of the "expiration time." The formula is

$$
E\left(D_{A R_{t}}\right)=\frac{A R_{t} \cdot e^{-R_{f} \cdot N}}{B}=\frac{A R_{t} \cdot e^{-\overline{r_{f_{t}}} \cdot n}}{B},
$$

where $A R_{t}$ is the book value on the fixing day, $n$ is the remaining payment days of accounts receivable, and $B$ is the market value.

2.3.3. The Buyer's Comprehensive Credit Default Risk Compensation. The risk compensation for the buyer's default credit default depends on the Probability of Default (PD), Loss Given Default (LGD), and Exposure at Default (EAD). As the EAD is known, and since it comes from the book value $\left(Y_{b v}\right)$ which depends on the specific circumstances on the pricing date, the key is to calculate $\mathrm{PD}$ and LGD.

(1) Calculate the Default Probability of the Buyer's Comprehensive Credit. This paper uses the improved KMV model. Suppose that the buyer's equity is the European call of the company's assets (underlying assets) and the corporate debt is treated as a debt pool; the total debt consists of the debt $D_{b}$ and other liabilities $D_{1-b}$. If the company's assets are not sufficient to repay the debt, the shareholders of the company will default. Improvements to the KMV model include two parts. The first one is about the default point. The size of the default risk is inversely proportional to the default distance. In 1997, according to the financial situation of US companies, the designer of the KMV model recommended that the default point should be "current liabilities $+0.5 *$ long term liabilities." Based on the design principle of the KMV model (the corporate debt value is the default point) and applied the innovations of $\mathrm{Ma}$ et al. [18], default distance consists of $D_{b}$ and $D_{1-b}$, this improves the analytical capabilities of the traditional models to suit the actual environment.

It is a time-variant indefinite constant, while the risk-free interest rate after pricing day is the same on all unexpired dates, satisfying Black-Scholes model assumptions.

Calculation on the probability of default of the listed companies mainly relies on a mature KMV model. Firstly, by utilizing the option principle, the calculation starts from estimating the company's asset value and volatility of return on assets based on the equity. Next, the default distance is calculated. Finally, the probability of default is deduced. This paper will not repeat the specific formula and process. We mainly provides solutions to calculate the probability of 
default about nonlisted companies, as shown in the following discussion.

Based on research findings of Sun and Liu in 2016 [19], assuming that the realized income $\left(V_{t}\right)$ of the unlisted company (the buyer) is subject to the lognormal distribution, when the corresponding accounts receivable of the seller expires, if the buyer's realized income $\left(V_{t}\right)$ is less than the value $\left(V_{B}\right)$ of debts that should be paid to the seller as due, breach of contract will occur. The condition of breach of contract is expressed as $V_{t}<V_{B}$. Then, calculation can be realized about the daily growth rate of the buyer's realization income $\mu$ and the volatility of realization income of assets $\sigma$. The volatility of realization income of assets can be derived from realization income of assets in each period. On the basis of this calculation, daily growth rate of the realization income of assets can be computed. The specific formula is as follows:

$$
\begin{aligned}
& \mu=\frac{1}{n-1} \sum_{i=1}^{n-1} \ln \frac{V_{i+1}}{V_{i}}+\frac{1}{2} \sigma^{2}, \\
& \sigma=\sqrt{\frac{1}{n-2} \sum_{i=1}^{n-1}\left(\ln \frac{V_{i+1}}{V_{i}}-\frac{1}{n-1} \sum_{i=1}^{n-1} \ln \frac{V_{i+1}}{V_{i}}\right)},
\end{aligned}
$$

where $V_{i}$ is realization income of assets in each period of time. The exact figure of $V_{i}$ is provided by the buyer. $n$ is the number of each period.

To calculate default distance DD and the default probability $p$, according to the assumption, realization income of assets follows the stochastic process-the standard geometric Brownian motion. The formula is as follows:

$$
d V_{t}=\mu V_{t} d t+\sigma V_{t} d z
$$

where $\mu$ is the daily growth rate of the buyer's realization income, $\sigma$ is the volatility of realization income of assets and $d z$ is the increment of realization income of assets during the Wiener process (the standard geometric Brownian motion).

When $t=0, V_{(0)}=V$, the above formula can be changed as follows:

$$
\ln V_{(t)}=V \exp \left\{\left(\mu-0.5 \sigma^{2}\right) t+\sigma \sqrt{t Z_{t}}\right\} .
$$

In this formula, it fits the normal distribution of $N(0,1)$, which means $Z_{t} \sim N(0,1)$.

When $t$ is more than zero, realization income of assets conforms to the normal logarithmic distribution. The mean and variance are shown here:

$$
\begin{aligned}
E\left[\ln V_{(t)}\right] & =\ln V+\mu t-0.5 \sigma^{2} t, \\
V_{a r}\left[\ln V_{(t)}\right] & =\sigma^{2} t .
\end{aligned}
$$

Event of default is $V_{t}<V_{B}$. Time interval is one receipt and payment cycle, namely indicating that the examination focuses on the probability of a credit default after a period.
When $T=1$, default probability can be expressed as follows:

$$
\begin{aligned}
P & =P\left[V_{t}<V_{B}\right]=P\left[\ln V_{t}<\ln V_{B}\right], \\
p & =N\left[\frac{\ln V_{t}-\ln V_{B}-\mu T+0.5 \sigma^{2} T}{\sigma \sqrt{T}}\right], \\
\mathrm{DD} & =\frac{\ln V_{t} / V_{B}+\mu T+0.5 \sigma^{2} T}{\sigma \sqrt{T}} .
\end{aligned}
$$

In this formula, the expected probability of default $p$ follows the normal distribution of $N(-\mathrm{DD})$. By the way, $N($.) here means the cumulative probability distribution function obeying standard normal distribution.

(2) Measure of the Default Loss Rate of the Buyer's Comprehensive Credit. The default loss rate of the buyer is a comprehensive variable, measuring the loss of the accounts receivable asset of the seller, including the expected risks and the unexpected risks from the buyer, the seller, and the environment. It is not only constrained by the buyer's financial and nonfinancial indicators, but also subject to the seller's business condition and nonsystemic risk of environment. Specific measurement methods include: based on the idea of the mean return to obtain the parameters through the industry credit history data; utilizing the mean or median as the threshold; referencing data from mature commercial banks; constructing the estimated range of the overall parameters according to the sample statistics; paying attention to experts' experience assessment; etc.

2.3.4. Seller Credit Composite Discount Risk Compensation. Violation of the seller also leads to the buyer's credit default. Outwardly, the direct factors associated with the seller's credit default are the quality, brand, price-quality ratio, credit commitment of the commodities selling to the buyer, and abilities of credit management and service capabilities. These factors can be divided into three dimensions. The quality, brand, and price reflect the credibility of the seller, which counts as the reputation dimension. Whether the seller can timely fulfill the commitment and contract manifests the seller's performance in credit issues, which refers to the performance dimension. Whether the seller can manage the credit granting of the buyer in accordance with the rules in the whole process reflects the seller's credit management and service capabilities, that is, the compliance dimension. How to measure the impact of such risks on the loss of credit assets of the receivables of the seller has been explored. From the existing literature, some scholars ignore the existence of the seller's credit comprehensive discount, and some scholars mechanically view these factors directly as independent variables. This paper constructs the Seller Credit Composite Discount Index (SCCDI) as an intermediate variable (Mediator) to measure its impact on the dependent variable (buyer's default loss rate).

In order to ensure comparability, this paper desires the SCCDI, and this index defines the variable range as $[0,1]$. Some indicators are applied by dummy variables; that is, 
under a nonrisk situation the variable scores 0 , otherwise the variable scores 1 . Some indicators, based on the sample business and industry historical data to establish the matrix, then map the credit rating to a specific figure. According to samples, some indicators are divided into five intervals [1,5] referencing measurement method of marketization by the American Traditional Foundation. Some indicators are divided into 11 levels $[0,10]$ by the Canadian Fraser study. The critical continuous function is established between the indicator value and the exponential value, and the corresponding score interval can be figured out [20]. Finally, combined with the fuzzy analytic hierarchy process (FAHP) and the expert method, the fuzzy matrix is set up according to the importance degree of assembled indicators and then fuzzy calculation on the exponential result can be realized.

\subsubsection{Risk Assessment from Environmental System. Environ-} mental risk includes possible systemic and nonsystemic risks. The main risk factors include macroeconomic cycle, national legal and policy risk, regional market risk, industry life cycle, and disaster risks such as earthquake and war. The loss-given default of the buyer is influenced by the systemic and nonsystemic risk factors of the environmental system. The systemic risk of the environmental system refers to the default risk of all enterprises in the region where the buyer is located, or industrial credit paralysis, which is usually caused by economic crises, financial crises, or irresistible natural disasters. The environmental systemic risk is not the focus of this paper. This paper focuses on studying the pricing and control management of credit assets in the enterprise accounts receivable without systematic risk.

This paper draws on the data envelopment analysis method to study and measure the environmental risk situation of the country, industry, and region where the buyer is located. According to the characteristics of the country, region, and industry where the buyer's customer is located, the nonsystematic risk of the environmental system is locked in the credit risk matrix to map its risk level.

Data Envelopment Analysis (DEA) is a good way to deal with multiobjective decision-making, as raised by scholars such as A. Charnes and W. W. Copper in 1978 based on the concept of "relative efficiency." The environmental system is split into three decision-making units (DMU): country, region, and industry. Each decisionmaking unit has $m$ various "input" and $s$ various "output." Setting the input vectors of a DMU $x=\left(x_{1}, x_{2}, \ldots, x_{m}\right)^{T}$ and the output vectors $y=\left(y_{1}, y_{2}, \ldots, y_{s}\right)^{T}, \mathrm{DMU}_{j}$ includes the corresponding input and output vectors as the following.

$$
\left\{\begin{array}{l}
x_{j}=\left(x_{1 j}, x_{2 j}, \ldots, x_{m j}\right)^{T}>0, \\
y_{j}=\left(y_{1 j}, y_{2 j}, \ldots, y_{s j}\right)^{T}>0, \\
x_{i j}>0, y_{r j}>0, \quad i=1,2, \ldots, m, r=1,2, \ldots, s .
\end{array}\right.
$$

Each decision unit $\mathrm{DMU}_{j}$ has a corresponding efficiency evaluation index:

$$
h_{j}=\frac{u^{T} y_{j}}{v^{T} x_{j}}=\frac{\sum_{r=1}^{s} u_{r} y_{r j}}{\sum_{i=1}^{m} v_{i} x_{i j}}, \quad j=1,2, \ldots, n .
$$

Utilizing $\mathrm{DMU}_{j}$ can build and compare the buyer's customers in different countries, regions, and industry credit risk environments.

2.4. Mathematical Expression of Model. The total expression of the complex system constructed in this paper is as follows:

$$
\begin{aligned}
Y & =\left(P, R_{j k}\right), \\
P & =\{B, S, E\}, \\
R_{j k} & =\left\{r_{j k} \mid j, k=B, S, E\right\},
\end{aligned}
$$

where $Y$ represents the total system; $P$ represents the subsystems, including $B, S$, and $E$. $B$ represents the buyer system, $S$ represents the seller system, and $E$ represents the environmental systems. The three systems, namely $B, S$, and $E$, interact each other. $R_{j k}$ represents the relationship matrix of $B, S$, and $E$, as shown here:

$$
\left(\begin{array}{ccc}
r_{E B} & r_{E S} & r_{E E} \\
r_{B B} & r_{B S} & r_{B E} \\
r_{S B} & r_{S S} & r_{S E}
\end{array}\right) .
$$

Formula (16) is divided into risk and risk-free mathematical expressions, respectively:

$$
\begin{gathered}
\qquad\left\{\begin{array}{l}
E\left(Y_{i v}\right)=Y_{b v} \cdot e^{-r_{f} \cdot N}=Y_{b v} \cdot e^{-\overline{r_{f t}} \cdot n} \\
E\left(Y_{i v}\right)=Y_{b v} \cdot e^{-\overline{r_{f t}} \cdot n}\left(1-P_{b} L_{b}\right)\left(1-P_{e}\right),
\end{array}\right. \\
\text { s.t. }\left\{\begin{array}{l}
n=E(D) \\
P_{b}=(1-\beta) P_{b}+\beta P_{b} \\
L_{b}=Y_{b}+Y_{b u} \\
Y_{b}=\alpha+\beta_{1} x_{1}+\beta_{1}^{\prime} x_{1}^{2}+\beta_{2} x_{2}+\beta_{3} x_{3} \ldots+\varepsilon \\
Y_{b u}=\lambda_{b u} E\left(Y_{b u}\right) \\
E\left(Y_{b u}\right)=P_{1} B_{w}+P_{2} L_{s}+P_{3} L_{e^{\prime}} .
\end{array}\right.
\end{gathered}
$$

where $Y_{i v}$ represents the intrinsic value of the credit assets of accounts receivable, $Y_{b v}$ represents the "book value" at time $t$, and $E\left(Y_{i v}\right)$ represents the expected value of the intrinsic value of the credit receivable of the receivable. Formula (16) meets the conditions of formula (17): $n$ is the number of days after the duration. $N$ is the number of years after the duration, $N * 360=n$. The following list explains the variables of formula (17): 
(1) Nonsystemic risk from the environment is introduced to affect the buyer default probability $L_{b}$ under a risky situation

(2) The default loss rate $L_{b}$ of the buyer's system consists of the expected loss rate $Y_{b}$ and the unexpected loss rate $Y_{b u}$. In 2005, the research of Wu [21] found that there is an internal relationship between unexpected loss and expected loss.

(3) $\lambda_{b u}$ is the expected loss multiplier, whose value depends on the probability distribution of the confidence interval and the credit loss. Assuming that the unexpected loss rate is subject to a normal distribution, when using 95\% as the confidence interval degree, $Y_{b u}$ is probably located in $\left[Y_{b u} \mp \sigma / \sqrt{n} *\right.$ 1.96].

(4) Risk-free $r_{f}$ is determined by the function $y=f\left(r_{f}\right)$, and $\overline{r_{f_{t}}}$ represents the average risk-free rate before pricing.

(5) $P_{e}$ and $P_{b}$ follow (18) and (19).

$$
\begin{gathered}
P_{b}=(1-\beta) P_{b}+\beta P_{b}, \\
P_{e}=\left\{\begin{array}{cc}
0, & \text { non-systematic risks, } \\
1, & \text { systematic risks. }
\end{array}\right.
\end{gathered}
$$

$(1-\beta) P_{b}$ in (19) refers to the probability of default from the buyer. $\beta P_{b}$ refers to the buyer's default probability caused by the nonsystemic risk from the environmental system and seller, and this paper uses a revised KMV model to directly measure the buyer's default probability. The systemic risk default probability $P_{e}$ of the buyer's environment system is a dummy variable, which is zero or one; that is, nonsystemic risk or systemic risk occurs.

$$
\begin{aligned}
\widehat{Y}_{i v} & =E\left(Y_{b v}\right)\left(1-P_{b} L_{b}\right)\left(1-P_{e}\right) \\
& =E\left(Y_{b v}\right)\left(1-P_{b} g\left(x_{1}, x_{2}, \ldots, x_{n}, f\left(B_{w}, L_{s}, L_{e^{\prime}}\right)\right)\right)\left(1-P_{e}\right),
\end{aligned}
$$

$$
\begin{aligned}
\widehat{Y}_{i v}^{\prime} & =E\left(Y_{b v}\right)\left(1-P_{b}^{\prime} L_{b}^{\prime}\right)\left(-P_{e}\right) \\
& =E\left(Y_{b v}\right)\left(1-P_{b}^{\prime} g^{\prime}\left(x_{1}^{\prime}, x_{2}^{\prime}, \ldots, x_{n}^{\prime}, f^{\prime}\left(B_{w}^{\prime}, L_{s^{\prime}}^{\prime} L_{e^{\prime}}^{\prime}\right)\right)\right)\left(1-P_{e}\right) .
\end{aligned}
$$

Formulas (20) and (21) are respectively the intrinsic value estimates of the accounts receivable assets before and after the control, namely $\widehat{Y}_{i v}$ and $\widehat{Y}_{i v}^{\prime} . E\left(Y_{b v}\right)$ is the risk exposure amount; $P_{e}$ is an uncontrollable variable belonging to the system risk; and $x_{1}, x_{2}, \ldots, x_{n}$ are the risk factors of the buyer's expected default loss rate, mainly composed of financial indicators to measure its ability to repay. The variance of the risk factors that affect the buyer's unanticipated default loss rate comes from the variable $B_{w}$ that measures the repayment willingness from the buyer's system as intermediate variable. $L_{s}$ and $L_{e^{\prime}}$ are respectively the intermediate variable that measures the factors influencing the seller's system and the nonsystem factor from the environmental system.

$P_{1}, P_{2}$, and $P_{3}$ can be derived from industry historical data. For research convenience, this paper utilizes an existing research achievement ( $\mathrm{Pu}$ and $\mathrm{Han})$ [22] as reference and shown in (22).

$$
\begin{aligned}
E\left(Y_{b u}\right) & =P_{1} B_{w}+P_{2} L_{s}+P_{3} L_{e^{\prime}} \\
& =0.6257 B_{w}+0.3568 L_{s}+0.0175 L_{e^{\prime}} .
\end{aligned}
$$

\subsection{Subsystem Variable Selection}

\subsubsection{Variants of the Buyer's System}

(1) Financial Indicators of the Buyer's System. Financial indicators of the buyer's system reflect the credit characteristics and solvency of enterprises. The credit risk revealed by these indicators is called the expected credit risk in this paper.

This paper draws lessons from the classification method of "the three characteristics" business principles of commercial banks, and puts forward the financial index system which measures buyer's solvency as shown in Table 1.

Through the correlation test and Hausman test of the above sample data variables, the final results are shown in Table 2 after the panel data regression analysis and three experiments and improvements of the model. The first model experiment uses the independent variables $X 1, X 2, X 3, X 5$, $X 6$, and $X 7 . X 7$ was found weak in significance, and the regression results of $X 1$ and $X 6$ and reality do not match. The second model experiment uses $X 1$, the square terms of $X 1, X 2, X 3, X 5$, and $X 6$, and the square term of $X 6$ as independent variables. It was found that the regression results of $X 1$ and its square terms, as well as $X 6$ and its square, are not consistent with reality. $X 2$ was found weak in significance. The third model experiment uses the independent variables $X 3$ and its square terms as well as $X 5$; it is found that the regression results are rather consistent with the reality. The last $R^{2}$ value among these three models is the smallest, reflecting that there are important variables not only included in the model, but also consistent with the facts basically. Because the pricing of corporate accounts receivables is quite complex, it is not enough to rely solely on financial indicators for explaination.

Table 3 shows the test results of the three independent variables' correlation in the third model. VIF results after panel data regression show that the VIF value of the OLS (ordinary least squares) regression result is less than 10 , thus the original hypothesis that the OLS regression model has a serious multiple collinearity problem can be rejected.

Hausman test results show the need to use the random effects model. Since the Prob $>\mathrm{chi}^{2}=0.1076>0.05$, the panel data should use the random effects model, that is, to accept the original hypothesis. 
TABLE 1: Buyer's solvency factors.

\begin{tabular}{|c|c|c|c|}
\hline Category & $\begin{array}{l}\text { Variable } \\
\text { dimension }\end{array}$ & Variable name and symbol & Index meaning and calculation formula \\
\hline \multirow{7}{*}{ Solvency } & \multirow{2}{*}{ Safety } & Asset-liability ratio $(X 1)$ & $\begin{array}{l}\text { Capital strength and long term solvency, } X 1=\text { total liabilities } / \text { total } \\
\text { assets }\end{array}$ \\
\hline & & Return on assets $(X 2)$ & $\begin{array}{c}\text { Integrated operating strength, } X 2=\text { EBIT (earnings before interest and } \\
\text { taxes) / total assets }\end{array}$ \\
\hline & \multirow{3}{*}{ Fluidity } & Current ratio $(X 3)$ & Short-term solvency, $X 3=$ current assets $/$ current liabilities \\
\hline & & Quick ratio $(X 4)$ & Liquid assets liquidity, $X 4$ = quick assets / current liabilities \\
\hline & & $\begin{array}{l}\text { Approximate accounts receivable turnover } \\
\text { or credit sales multiple (X5) }\end{array}$ & $\begin{array}{l}\text { Operating capacity, } X 5 \text { = prime operating revenue } /[\text { (balance of } \\
\text { accounts receivable at the beginning of the period }+ \text { balance of } \\
\text { accounts receivable at the end of the period }) / 2]\end{array}$ \\
\hline & \multirow{2}{*}{ Efficiency } & Income growth rate $(X 6)$ & $\begin{array}{l}\text { Profitability development capacity, } X 6=(\text { income for the year / income } \\
\text { for the previous year }-1) * 100 \%\end{array}$ \\
\hline & & Profit growth rate $(X 7)$ & $\begin{array}{c}\text { Current profitability, } X 7=\text { (profit for the year / profit for the previous } \\
\text { year }-1) * 100 \%\end{array}$ \\
\hline
\end{tabular}

Note: $X 3$ and $X 4$ shows multiple collinearity; $X 4$ is removed after comprehensive comparison.

TABLE 2: Three model experimental evolution results.

\begin{tabular}{|c|c|c|c|}
\hline Variable & Industry default loss rate (I) & Industry default loss rate (II) & Industry default loss rate (III) \\
\hline Asset-liability ratio $(X 1)$ & $-1.671212^{* *}$ & 0.014867 & \\
\hline Asset profitability (X2) & -0.2520199 & -0.0158547 & \\
\hline Current ratio $(X 3)$ & $-0.2530928^{*}$ & $-0.0047897^{* * *}$ & $-0.004936^{* *}$ \\
\hline $\begin{array}{l}\text { Approximate accounts receivable } \\
\text { turnover ratio }(X 5)\end{array}$ & $-0.0036502^{* *}$ & $-0.0000371^{* * *}$ & $-0.0000528^{* * *}$ \\
\hline Income growth ratio $(X 6)$ & 0.3298607 & 0.0043544 & \\
\hline Profit growth rate $(X 7)$ & -0.00052 & & \\
\hline Asset-liability ratio ( $X 1$ square terms) & & -0.0379262 & \\
\hline Current ratio ( $X 3$ square terms) & & & $0.0003357^{* *}$ \\
\hline Income growth ratio ( $X 6$ square terms) & & $-0.0081017^{*}$ & \\
\hline Constant number & $4.653968^{* * *}$ & $0.0476511^{* * *}$ & $0.0418854^{* * *}$ \\
\hline$R^{2}$ & $4.91 \%$ & $7.53 \%$ & $5.60 \%$ \\
\hline
\end{tabular}

Note: ${ }^{*},{ }^{* *}$, and ${ }^{* * *}$ represent significance levels of $90 \%, 95 \%$, and $99 \%$, respectively.

TABLE 3: Regression model VIF value.

\begin{tabular}{lcc}
\hline Variable & VIF & 1/VIF \\
\hline Current ratio X3 & 4.42 & 0.226192 \\
The square of the current ratio X3 & 4.69 & 0.213126 \\
$\begin{array}{l}\text { Approximate accounts receivable } \\
\text { turnover rate } X 5\end{array}$ & 1.16 & 0.858769 \\
Mean VIF & 3.43 & \\
\hline
\end{tabular}

Equation (23) is the result of the third model regression results:

$$
\begin{aligned}
\widehat{y}_{i t}= & 0.0418854-0.004936 x_{3 i t}+0.0003357 x_{3 i t}^{2} \\
& -0.0000528 x_{5 i t}+u_{i}+\varepsilon_{i} .
\end{aligned}
$$

Here $i$ represents the firm, $t$ represents the time, $u_{i}$ is the random error term related to the individual effect, and $\varepsilon_{i}$ is the error term related to the other factors except the individual effect.

As shown in Table 2, the model was statistically significant at $99 \%$ significance level, Prob $>\mathrm{chi}^{2}=0.0000<0.001$. The current ratio $X 3$ has a negative explanatory effect on the industry default loss rate at $95 \%$ significance level. The square of the current ratio $X 3$ has a positive explanatory effect on the default loss rate at $95 \%$ significance level. The approximate turnover rate of accounts receivable $X 5$ has a negative explanatory effect on the loss rate of industry defaults at the significance level of $99 \%$.

The third model shows that when the liquidity ratio of the short-term solvency is lower than the threshold value of 14.7036, that is, when the enterprise's current ratio is below the level, the default loss rate will decrease as the enterprise's liquidity ratio increases. When the enterprise's liquidity ratio is higher than the threshold of 14.7036 , with the increase in corporate liquidity ratio, the company's default loss rate will rise. When the enterprise liquidity is too much, or the current 
TABLE 4: Buyer nonfinancial index cluster.

\begin{tabular}{|c|c|c|c|}
\hline Risk classification & $\begin{array}{c}\text { Symbol and importance } \\
\text { degree, weight }\end{array}$ & Index and range & Fractional quantification instructions \\
\hline \multirow{10}{*}{$\begin{array}{l}\text { The buyer's willingness to } \\
\text { repay and refinancing } \\
\text { capacity, and the credibility } \\
\text { of the business and } \\
\text { entrepreneur }\end{array}$} & $\mathrm{I} 1 ; 2 ; 0.1190$ & $\begin{array}{l}\text { (i) Basic credit information of } \\
\text { enterprises }[0,1]\end{array}$ & \multirow{7}{*}{$\begin{array}{l}0 \text { means honesty, } 1 \text { means } \\
\text { dishonesty. The higher the score is, } \\
\text { the higher the degree of dishonesty is } \\
\text { and the higher the degree of default } \\
\text { loss is. }\end{array}$} \\
\hline & $\mathrm{I} 2 ; 4 ; 0.1857$ & $\begin{array}{l}\text { (ii) Corporate Public Credit } \\
\text { Information Index }[0,1]\end{array}$ & \\
\hline & $\mathrm{I} 3 ; 4 ; 0.1857$ & $\begin{array}{l}\text { (iii) Corporate Financial Credit } \\
\text { Information Index }[0,1]\end{array}$ & \\
\hline & I $4 ; 3 ; .1524$ & $\begin{array}{l}\text { (iv) Enterprise market credit } \\
\text { information index }[0,1]\end{array}$ & \\
\hline & $\mathrm{I} 5 ; 1 ; 0.0857$ & (v) Entrepreneur quality index $[0,1]$ & \\
\hline & I6; $3 ; 0.1524$ & (vi) Entrepreneur Loss Index $[0,1]$ & \\
\hline & I7; $2 ; 0.1191$ & $\begin{array}{l}\text { (vii) Entrepreneur trustworthy } \\
\text { index }[0,1]\end{array}$ & \\
\hline & \multirow{3}{*}{ Others; $\varepsilon$} & Enterprise catastrophic indicators; & \multirow{3}{*}{ Only exists in extreme cases. } \\
\hline & & Entrepreneur disastrous indicators; & \\
\hline & & Others & \\
\hline
\end{tabular}

liabilities are few, or both of them are true, the enterprise has a superfluous current ratio; namely, it means an inefficient enterprise finance management, and the company's default loss rate would rise instead of fall.

Based on the tests of the three models and the experiment data, ultimately only the current ratio $(X 3)$ and approximate accounts receivable turnover ratio (X5) pass through the test. Research shows that the default loss of accounts receivable is a loss of default in current assets, and should be mainly focused on short-term solvency. Therefore, it is also reasonable that finally only these two indicators have passed the test. Further analysis shows that these two indicators in fact also reflect current assets, current liabilities, operating income, and accounts receivable. Moreover, from the perspective of corporate financial management, a higher current ratio is not better. The international popular view is that the current ratio 2 is the ideal level, which shows that the company has a good short-term solvency. This sample study above shows that once the current ratio of the trade industry is more than 14, there will be an antidirectional effect.

(2) Nonfinancial Indicators of the Buyer's System. The financial situation of the enterprise is the embodiment of the final management results, but the financial data cannot measure all its credit information, so the buyer's credit information must be measured from the nonfinancial indicators. Entrepreneurship is the embodiment of the enterprise, and corporate reputation and the credibility of entrepreneurs are related to entrepreneurs. Measuring the credit risks of the buyer's business, it is necessary to consider the credit risk of the entrepreneur at the same time.

Nonfinancial indicators mainly reflect the willingness of enterprises to repay, refinancing capacity, and reputation of businesses and entrepreneurs. Table 4 shows the nonfinancial indicator variables related to the buyer. This information is comprehensively reflected by building index clusters. The monitoring period coincides with the probability of default and the rate of default loss. It is generally set to the date of pricing (if necessary, you can continue to trace forward). Variables are set to consider the dimension processing; all the variables are normalized.

The specific steps are as follows:

(1) Determine the evaluation index cluster. $I \in\left\{I_{1}, I_{2}\right.$, $\left.I_{3}, \ldots, I_{7}, \varepsilon_{I}\right\} . \varepsilon_{I}$ represents some catastrophic indicators and others that are generally negligible. Disastrous indicators are small probability events, and "others" are valid indicators to be added in the future.

(2) Determine the evaluation indicator sets. $U \in\left\{U_{1}\right.$, $\left.U_{2}, \ldots, U_{n}\right\}$.

(3) Determine the comments of evaluation indicator sets. $V=\left\{V_{1}, V_{2}, V_{3}, V_{4}, V_{5}, \varepsilon_{V}\right\}$ or $\{Y, N\}$.

The value given to the $[0,1]$ interval is based on the value of the dummy variable of 0 or 1 . According to different variables, we apply quantile, median as well as other fuzzy mathematical methods to quantify the indicator attribute separately to $(1,2,3,4$, or 5$)$ and relate the values to $[0$, $0.25,0.5,0.75$, or 1$]$. The higher the value is, the more serious the loss of trust is and the higher the rate of loss of default is. Business and entrepreneur catastrophic variables, $\varepsilon_{v}$ refers to accidents that the buyer's business suffer from war, plague, earthquake, tsunami, and other serious natural disasters, or human factors such as entrepreneurs being imprisoned, suffering from serious illness, etc.

(4) Determine the weight of the index and inidicators. All the indicators are classified according to the degree of importance, then compared with each other. We establish a matrix according to the degree of importance of the relationship between each other, and solve the weight. 
TABLE 5: Seller's credit management index indicators.

\begin{tabular}{|c|c|c|c|}
\hline Dimension & Indicator, symbol, and score content & $\begin{array}{c}\text { Importance degree and } \\
\text { weight }\end{array}$ & Further explanation of variables \\
\hline & $\begin{array}{l}\text { S1: whether the commodity quality level is } \\
\text { higher than the industry average }(0,0.5 \text {, and } 1 \\
\text { respectively mapped below, flat, and above) }\end{array}$ & $4,0.1393$ & \\
\hline \multirow[t]{2}{*}{ Reputation } & $\begin{array}{l}\text { S2: whether the commodity brand effect is } \\
\text { higher than the industry average }(0,0.5 \text {, and } 1 \\
\text { respectively mapped below, flat, and above) }\end{array}$ & $4,0.1393$ & \\
\hline & $\begin{array}{l}\text { S3: whether the commodity price-performance } \\
\text { ratio is higher than the industry average }(0,0.5 \text {, } \\
\text { and } 1 \text { respectively mapped below, flat, and } \\
\text { above) }\end{array}$ & $4,0.1393$ & \\
\hline Performance & $\begin{array}{l}\text { S4: whether the seller has fulfilled contracts } \\
\text { and commitments to the buyer ( } 1 \text { and } 0 \\
\text { respectively mapped to yes and no) }\end{array}$ & $5,0.1679$ & \\
\hline \multirow[t]{4}{*}{ Compliance } & $\begin{array}{l}\text { S5: whether there is management and service } \\
\text { in advance ( } 1 \text { and } 0 \text {, respectively mapped to } \\
\text { yes and no) }\end{array}$ & $3,0.1107$ & $\begin{array}{c}\text { Customer files, credit sales reporting system, } \\
\text { contract management, performance } \\
\text { guarantee, and so on. }\end{array}$ \\
\hline & $\begin{array}{l}\text { S6: whether there is management and service } \\
\text { during the trade ( } 1 \text { and } 0 \text { respectively mapped } \\
\text { to yes and no) }\end{array}$ & $3,0.1107$ & $\begin{array}{l}\text { Customer moving resource management } \\
\text { system, including the management of } \\
\text { customers, delivery orders, invoices and } \\
\text { collection process. }\end{array}$ \\
\hline & $\begin{array}{l}\text { S7: whether there is management and service } \\
\text { afterward ( } 1 \text { and } 0 \text { respectively mapped to yes } \\
\text { and no) }\end{array}$ & $3,0.1107$ & Reconciliation measures and means. \\
\hline & $\begin{array}{l}\text { S8: whether there are special departments or } \\
\text { functions of departments engaged in } \\
\text { management and service ( } 1 \text { and } 0 \text {, respectively } \\
\text { mapped to yes and no) }\end{array}$ & $2,0.0821$ & $\begin{array}{l}\text { Credit management responsibility is } \\
\text { implemented to departments and individuals. }\end{array}$ \\
\hline
\end{tabular}

2.5.2. Variants of the Seller's System. In this paper, we study the credibility and credit management ability of creditors from three aspects: reputation (integrity), performance, and degree of compliance. We study the whole process to build a seller's corporate credit management index to assess the seller's credit level. The indicators are reversed compared with the default loss rate, as shown in Table 5.

2.5.3. Variants of Environment System. When defining the inner value of accounts receivable credit assets for the seller, every factor which influences the environment besides buyer and seller, such as country risk, region risk, and industry exposure, should be considered. There are 2 kinds of risks in the environment system, systemic risk and unsystematic risk. We will start from the availability of data and the feature of variants, measuring relevant country about convenience of operating a business, cost, and law environment, which the World Bank considered. Then, we create the index of environment factors which influences the sellers' risks of accounts receivable credit assets. This is shown in Table 6. Every country, region, and industry is a different Decision-Making Unit (DMU), which will be explained by the Data Envelopment Analysis (DEA); it can solve the relative degree of credit risk respectively. It contrasts the effectiveness of management risk control between different decision-making units by inputting and outputting indicators. The DEA value will be considered as the entire environment situation coming from the buyer.

\subsection{Correlations between Subsystems and Variables}

2.6.1. Weight of Indicators and Subindexes. In this paper, the impacts of the nonfinancial indexes of the buyer system, and the indexes of the seller system and environment system on the rate of default losses, are assessed by compiling those indexes as intermediate variables. The weights of indexes (including the subindexes) are based on the importance of those indexes that is assessed by experts and finally determined by FAHP. Specifically, the first step is to establish a fuzzy judgment matrix. After the establishment of a hierarchical structure, the ratios of importance are determined by pairwise comparison of indexes from the same level and internal indexes from different levels and filled in the matrix.

The second step is to find the indicators weight in certain level. The calculation method is as follows: first, calculate the sum of the elements of each row of the judgment matrix $\sum_{j=1}^{n} b_{i j}, i=1,2, \ldots, n$; second, set the parameter $\alpha$ and let $\alpha$ satisfy $\alpha \geq(n-1) / 2$; third, use the number of factors $n$, parameter $\alpha$, and the sum of each row of elements $\sum_{j=1}^{n}$ 


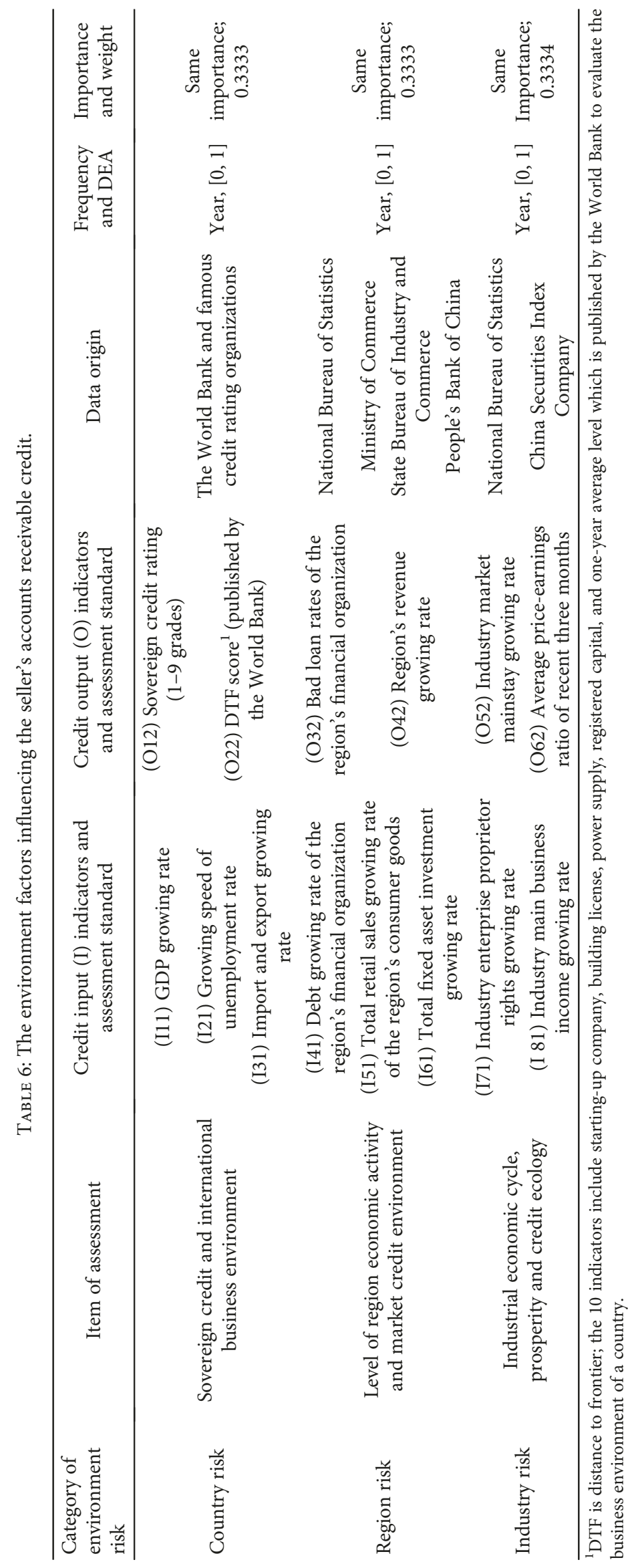


TABLE 7: The main hedging parameters of subsystems.

\begin{tabular}{|c|c|c|c|c|}
\hline Name & Subsystem & Basic point & Critical point & Control purpose \\
\hline $\operatorname{Delta}(\triangle)$ & Buyer & $\begin{array}{l}\text { Industry average } \\
\text { and extreme value }\end{array}$ & $\begin{array}{l}\text { Depending on the specific } \\
\text { companies }\end{array}$ & Control default probability of buyers $\left(P_{b}\right)$ \\
\hline Gamma $(\Gamma)$ & Buyer & $\begin{array}{l}\text { Industry average } \\
\text { and extreme value }\end{array}$ & $\begin{array}{l}\text { Depending on the specific } \\
\text { company }\end{array}$ & Control default loss rate of buyers $\left(L_{b}\right)$ \\
\hline Theta $(\Theta)$ & Seller & $\begin{array}{l}\text { Industry average } \\
\text { and extreme value }\end{array}$ & $\begin{array}{l}\text { Depending on the specific } \\
\text { company }\end{array}$ & Control the defaulted loss rate of sellers $\left(L_{s}\right)$ \\
\hline Vega $(v)$ & Environment & $\begin{array}{l}\text { Historical average } \\
\text { and extreme value }\end{array}$ & $\begin{array}{l}\text { Depending on the country, } \\
\text { region and industry of the } \\
\text { buyer }\end{array}$ & $\begin{array}{l}\text { Default loss rate caused by the nonsystematic risk } \\
\text { of controlled environment }\left(L_{e}^{\prime}\right)\end{array}$ \\
\hline Rho $(\rho)$ & Environment & $\begin{array}{l}\text { Historical average } \\
\text { and extreme value }\end{array}$ & $\begin{array}{l}\text { Depending on the country, } \\
\text { region and industry of the } \\
\text { buyer }\end{array}$ & $\begin{array}{c}\text { Positive impact and promotion of environmental } \\
\text { optimization, impact and reduction of possible } \\
\text { systemic risk }\left(P_{e}\right)\end{array}$ \\
\hline
\end{tabular}

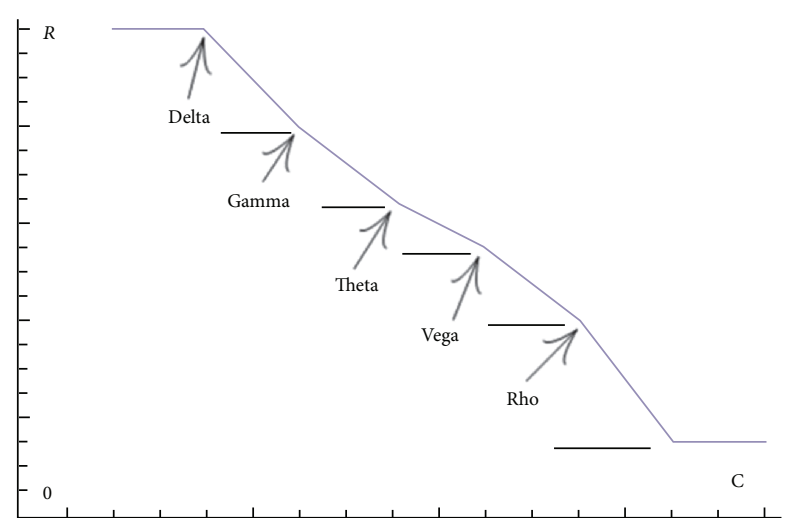

FIgURE 3: The risk changes under effective control of parameters.

$b_{i j}, 1=1,2, \ldots, n$ to calculate the weight of relative importance (24).

$$
w_{i}=\frac{\sum_{j=1}^{n} b_{i j}}{n \alpha}+\frac{1}{n}-\frac{1}{2 \alpha}, \quad i=1,2, \ldots, n
$$

The third step is to order the overall ranking of the hierarchy. Calculate the weight relative importance of every index to the target. The weight value is the product of the weights of each index to the criterion and the weight of the criterion to the target.

2.6.2. Variable Control Management. Cybernetics and operational research principles studied how to achieve the overall optimal goal under certain constraints, or how to gain the maximum benefit of limited resources by the use and planning of various resources.

For the entire pricing system, multiobjective optimization is used to find Pareto optimality. For the environment system, robust optimization is used to get the optimal solution under the worst condition and the constraint condition is disturbed; it is also used to analysing quantitatively the validityof the control of management risk in the environment. For the buyer system, bilevel optimization is used; sometimes an optimization is nested outside of another optimization. Some thresholds are estimated by using interval estimation instead of point estimation. For the seller system, the stochastic programming is used to get the expectation of the maximum objective function. In practice, the industry average, historical average, maximum, minimum, and other indexes are sensitive target indicators. Table 7 shows the main hedging parameters for the subsystem.

Formula (25) and Figure 3 shows the change of the five controlled parameters. $P_{b}^{\prime}, L_{b}^{\prime}, L_{s}^{\prime}, L_{e}^{\prime}$, and $P_{e}^{\prime}$ are the corresponding controlled values, that is, the value under the effective control of all hedging parameters. Since the value of risks of all aspects $(R 1, R 2, R 3, R 4$, and $R 5)$ is near zero, the overall risk $(R)$ would tend to be the smallest.

$$
\left\{\begin{array}{cl}
\{R 1, R 2, R 3, R 4, R 5\} \in R, & \\
P_{b}^{\prime}=\Delta * P_{b} \in R 1, \quad \Delta \in[0,1], \\
L_{b}^{\prime}=\Gamma * L_{b} \in R 2, \quad \Gamma \in[0,1], \\
L_{s}^{\prime}=\theta * L_{s} \in R 3, \quad \theta \in[0,1], \\
L_{e^{\prime}}^{\prime}=v * L_{e^{\prime}} \in R 4, \quad v \in[0,1], \\
P_{e}^{\prime}=(1-\rho) * P_{e} \in R 5, \quad \rho \in\{0,1\} .
\end{array}\right.
$$

\section{Empirical Test}

3.1. Calculation of Real Book Value and Default Probability. The JDG company in Beijing had two accounts receivables on May 23, 2017. The sum of accounts receivable is 15.8 million RMB and its debtor is a listed trading company (HH company in Jiangsu province, China) with a credit period of 3 months; in other words, this accounts receivable will expire on August 22, 2017. Another sum of accounts receivable is 9.66 million $\mathrm{RMB}$ and its debtor is a nonlisted manufacturer (XY company in Beijing, China) with a credit period of 6 months; in other words, this accounts receivable will expire on November 22, 2017. The JDG company in Beijing applies for the pricing of the two accounts receivable on June 1, 2017 (unsettled 
TABLE 8: Relevant financial data of $\mathrm{HH}$ joint stock company of Jiangsu province.

\begin{tabular}{lc}
\hline Index & Value \\
\hline Debt value, $D$ (100 million RMB) & 208.43 \\
Risk-free rate, $r$ (May 31) & $3.15 \%$ \\
Closing price (May 31, RMB) & 7.38 \\
Share capital (share) & $2,242,433,192$ \\
Total market capitalization & 165.49 \\
(May 31, 100 million RMB) & $25.21 \%$ \\
\hline
\end{tabular}

period is 0.225 years) and June 6, 2017 (unsettled period is 0.46 years).

The book value of the first sum of accounts receivable (Account 1) is 15.8 million RMB; the real book value of Account 1 is 15.3075 million RMB, and the risk-free rate was selected as $3.15 \%$. The specific calculation is as follows:

$$
\begin{aligned}
\bar{r}_{\mathrm{ft}} & =\frac{\sum_{n=1}^{20} r_{f n}}{20}=3.15 \%=0.0863 \% 0, \\
E\left(Y_{i v}\right) & =Y_{b v} \cdot e^{-\bar{r}_{\mathrm{ft}} \cdot n}=1580 * e^{-0.0000863 * 367} \\
& =15.3075 \text { million RMB. }
\end{aligned}
$$

The book value of the first sum of accounts receivable (Account 2) is 9.66 million RMB; the "real" book value (namely discounted book value) of Account 2 is 9.3441 million RMB, and the risk-free rate was selected as $3.29 \%$. The specific calculation is as follows:

$$
\begin{aligned}
\bar{r}_{\mathrm{ft}} & =\frac{\sum_{n=1}^{20} r_{f n}}{20}=3.29 \%=0.0901 \%, \\
E\left(Y_{i v}\right) & =Y_{b v} \cdot e^{-\overline{r_{\mathrm{ft}}} \cdot n}=96 * e^{-0.0000901 * 369} \\
& =9.3441 \text { million RMB. }
\end{aligned}
$$

Since the debtor of Account 1 is a listed company, the improved KMV model is used to get the default probability of Account 1, 1.315065006561802e-028. The default probability $R b$ is approximately 0 ; the default of accounts receivable can hardly happen. The company's specific financial data is shown in Table 8 .

Since the debtor of Account 2 is a nonlisted company, the improved KMV model is used to get the default probability of Account 2. First, the historical data of the income of liquidation of assets of this company is used to get its daily growth rate and volatility. They are listed respectively as follows:

$$
\begin{aligned}
& \mu=-0.002762655, \\
& \sigma=0.020770556 .
\end{aligned}
$$

The followings as known: $V_{t}=9.34$ million RMB and $V_{b}=9.3441$ million RMB. The calculation process of default probability is as follows:

$$
\begin{aligned}
T & =0.46, \\
\mu & =-0.002762655, \\
\sigma & =0.020770556, \\
\mathrm{DD} & =\frac{\ln V_{t} / V_{b}+\mu T+0.5 \sigma^{2} T}{\sigma \sqrt{T}}, \\
P & =N(-\mathrm{DD}),
\end{aligned}
$$$$
\text { Get } P=0.551087 \text {. }
$$

Let $\lambda=0.6$. The multiplier is determined by historical big data that is matched by the pricing system according to the buyers and sellers of transactions.

It is assumed that the artificial information entropy $E$ $\left(Y_{b u}\right)$ is near the true unexpected loss rate $Y_{b u}$ after continuing iteration and there is a complete linear relationship between the true unexpected loss rate $Y_{b u}$ and $E\left(Y_{b u}\right)$.

The basic information of the two accounts receivable is shown in Table 9.

3.2. Calculation of Final Inner Value on Credit Assets of Accounts Receivable. We count other variables in order to get the final intrinsic value of the two accounts receivable. Tables 10 and 11 show the factors coming from the environment system and actual computations by DEA.

The above related numbers were input into the model and after operating the model, we get the value of risk loss rate, default loss rate, and intrinsic value of the two accounts receivable. The specific value is shown in Table 12 .

The results of the relevant parameters before and after the adjustment is shown in Table 13:

After the idealized adjustment of the hedging parameters, the intrinsic value of the two accounts receivable should be 15.3075 million RMB and 9.3441 million RMB.

\section{Conclusion}

This paper studied the formation and value realization of enterprises' accounts receivable credit assets based on the analysis of the relationship and inner theory between buyers, sellers, and environment systems, created the BEST pricing model, and analysed the change of inner accounts receivable credit assets value before and after the pricing system was applied with the control management. The dynamization of risk-free rate, duration of age, and the improvement of the KMV model are the important nodes of this model.

Surrounding the pricing model, we screened the independent variables, intermediate variables, and control variables which are related to the dependent variable. The book value of accounts receivable, age, and risk-free rate are the pricing independent variables which influence the enterprises' accounts receivable credit assets. The financial risk and nonfinancial risk which come from the buyer system, the credit 
TABLE 9: Basic information of the accounts receivable of JDG company .

\begin{tabular}{lcc}
\hline Variable & The first sum of accounts receivable & The second sum of accounts receivable \\
\hline Real book value $Y_{b u}$ (ten thousand RMB) & 1530.75 & 934.41 \\
Expected delivery time $t$ (year) & 0.225 & 0.46 \\
Dynamic risk-free rate & $3.15 \%$ & $3.29 \%$ \\
Default probability, $R_{b}$ & $1.315065006561802 e-028$ & 0.551087 \\
Lambda & 0.6 & 0.6 \\
Environmental system default probability, $P_{e}$ & 0 & 0
\end{tabular}

TABLE 10: Input and output factors impacted the environment system.

\begin{tabular}{|c|c|c|}
\hline $\begin{array}{l}\text { Category of } \\
\text { decision-making } \\
\text { unit }\end{array}$ & Input indicators (China/US/India) & Output indicators (China/US/India) \\
\hline \multirow{3}{*}{ Country } & I11: GDP growth rate $(6.70 \%, 2.10 \%, 7 \%)$ & O11: sovereign credit rating $(\mathrm{AA}-/ \mathrm{AA}+/ \mathrm{BBB}-)$ \\
\hline & I12: development rate of unemployment rate $(1.22,0.94,1)$ & $\begin{array}{l}\text { O12: DTF (Business Environment Index) }(64.28,82.45 \text {, } \\
\text { 55.27) }\end{array}$ \\
\hline & $\begin{array}{l}\text { I13: growth rate of import and export }(-0.90 \%,-2.02 \% \text {, } \\
\qquad-5.80 \%)\end{array}$ & \\
\hline \multirow{3}{*}{ Province } & I14: exchange rate $(6.7153,1,67.1993)$ & \\
\hline & Input Index (Beijing/Shanghai Jiangsu province) & Output Index (Beijing/Shanghai/Jiangsu province) \\
\hline & $\begin{array}{l}\text { I21: growth rate of provincial financial institutions' debt } \\
\qquad(9.02 \%, 14.62 \%, 12.80 \%)\end{array}$ & $\begin{array}{l}\text { O21: growth rate of provincial financial institutions bad } \\
\text { debt }(0.67 \%, 1.39 \%, 0.77 \%)\end{array}$ \\
\hline \multirow{5}{*}{ Industry } & $\begin{array}{l}\text { I22: growth rate of total retail sales of social consumer goods } \\
\text { in this province }(6.21 \%, 10.93 \%, 8.85 \%)\end{array}$ & $\begin{array}{l}\text { O22: growth rate of general public budget revenue } \\
\qquad(7.50 \%, 5.00 \%, 16.10 \%)\end{array}$ \\
\hline & $\begin{array}{l}\text { I23: growth rate of fixed assets investment in the whole } \\
\text { society }(5.90 \%, 7.50 \%, 6.30 \%)\end{array}$ & \\
\hline & $\begin{array}{l}\text { Input Index (wholesale and retail/pharmaceutical } \\
\text { manufacturing/automotive manufacturing) }\end{array}$ & $\begin{array}{l}\text { Output Index (wholesale and retail/pharmaceutical } \\
\text { manufacturing/automotive manufacturing) }\end{array}$ \\
\hline & $\begin{array}{l}\text { I31: growth rate of the industry main business income } \\
\qquad(-5.43 \%, 10.19 \%, 4.79 \%)\end{array}$ & $\begin{array}{l}\text { O31: average price-earnings ratio for the last year in this } \\
\text { industry }(44.55,53.09,21.82)\end{array}$ \\
\hline & $\begin{array}{c}\text { I32: growth rate of owners' equity of companies in this } \\
\text { industry }(6.16 \%, 19.69 \%, 11.83 \%)\end{array}$ & $\begin{array}{c}\text { O32: growth rate of companies in this industry }(0.81 \% \text {, } \\
44.69 \%, 8.25 \%)\end{array}$ \\
\hline
\end{tabular}

TABLE 11: Validity coefficients of DEA and associated weights.

\begin{tabular}{lccc}
\hline $\begin{array}{l}\text { Category of decision- } \\
\text { making units }\end{array}$ & $\begin{array}{c}\text { Decision-making } \\
\text { units }\end{array}$ & Validity & Weight \\
\hline \multirow{4}{*}{ Country } & China & 1 & \\
& United States & 1 & 0.3333 \\
& India & 0.708 & \\
Provinces & Beijing & 1 & \\
& Shanghai & 1 & 0.3333 \\
& Jiangsu province & 0.781 & \\
& Wholesale and retail & 1 & \\
Industry & $\begin{array}{c}\text { Pharmaceutical } \\
\text { manufacturing }\end{array}$ & 0.585 & 0.3334 \\
& Automotive & 1 & \\
& manufacturing & & \\
\hline
\end{tabular}

Note: for the cases in this paper, we only list three decision-making units; more decision-making units can be added in other practices. management risk which comes from seller system, and all kinds of risks from the environment system will influence enterprises' inner accounts receivable credit assets value. We chose 3 financial indicators related to buyers as explanatory variables, and considered them as expected risks. The explanatory variables of unexpected risk include 63 nonfinancial indicators of the buyer system, 8 indicators of the seller system and 14 indicators of the environment system. Every index belongs to an intermediate variable. There are all kinds of nonfinancial variables, including the relationship between every intermediate variable's weight setting based on the experts' method and fuzzy analytical hierarchy process. At last, to make sure of the effective control management of the model, 5 hedging parameters are built, which are used to control buyer default probability, buyer default loss rate, seller default loss rate, unsystematic environment risk and systemic environment risk.

The 2 cases above demonstrated that the feasibility and rationality of both the listed company and nonlisted 
TABLE 12: Results.

\begin{tabular}{lcc}
\hline Variable & The first sum of accounts receivable & The second sum of accounts receivable \\
\hline Expected loss rate, $Y_{b}$ & 0.0366 & 0.0359 \\
Unexpected loss rate, $Y_{b u}$ & 0.0015 & 0.1983 \\
Default loss rate of buyers, $B_{w}$ & 0.1889 & 0.1995 \\
Defaulted loss rate of sellers, $L_{s}$ & 0.0697 & 0.5697 \\
Defaulted loss rate of environment, $L_{e}{ }^{\prime}$ & 0.0730 & 0.1384 \\
Default loss rate, $L_{b}$ & $(0.0224,0.0538)^{*}$ & $(0.2185,0.2499)^{*}$ \\
Estimated value of accounts receivable, $Y_{i v}$ & 1530.75 & $(805.73,821.90)^{*}$
\end{tabular}

Note: $(\mathrm{a}) *$ indicates $95 \%$ confidence interval value; (b) the coefficient of the impact of indexes of the buyer system, the seller system, and the environmental system on the rate of unexpected losses are $62.57 \%, 35.68 \%$, and $1.75 \%$ respectively quoted by research findings (Pu and Han) [22]; (c) the rate of unexpected losses includes the adjustment of the multiplier $\lambda$.

TABle 13: Parameters of risk after adjustment.

\begin{tabular}{|c|c|c|}
\hline \multirow[b]{2}{*}{ Parameters } & \multicolumn{2}{|c|}{ The optimal results before and after adjustment } \\
\hline & $\begin{array}{l}\text { The first sum of } \\
\text { accounts receivable }\end{array}$ & $\begin{array}{l}\text { The second sum of } \\
\text { accounts receivable }\end{array}$ \\
\hline $\operatorname{Delta}(\triangle)$ & $0 \rightarrow 0$ & $0.5697 \rightarrow 0$ \\
\hline Gamma $(\Gamma)$ & $0.0366 \rightarrow 0$ & $0.0359 \rightarrow 0$ \\
\hline Theta $(\Theta)$ & $0.0696 \rightarrow 0$ & $0.5696 \rightarrow 0$ \\
\hline $\operatorname{Vega}(v)$ & $0.0730 \rightarrow 0$ & $0.1384 \rightarrow 0$ \\
\hline Rho $(\rho)$ & $0 \rightarrow 0$ & $0 \rightarrow 0$ \\
\hline$Y_{i v}$ & $15.3075 \rightarrow 15.3075$ & $(8.0573,8.2190) \rightarrow 9.3441$ \\
\hline
\end{tabular}

company are tested. The outstanding accounts receivable was tested for duration, the risk-free rate was dynamically estimated, and the corrected KMV model was used to evaluate the default rate of 2 kinds of enterprises. The result showed that the assessed value is basically in line with reality. The inner value is optimized and enterprise accounts receivable credit assets risk is reduced through controlling all the variables in the management system and adjusting the hedging parameter. The results about one case involving a listed company are: the buyer's default rate is nearly 0 ; after control management, the total inner value hardly changed; the assessed value is the optimized one which is 15.3075 million RMB. The results about another case are: obeying the 95\% confidence level first; before control management, the assessed interval of the nonlisted company's buyer's inner value is $(8.0573,8.2190)$ million RMB; after control management, its final inner value gets closer to the ideal value of 9.3441 million RMB.

\section{Data Availability}

The data used to support the findings of this study are available from the corresponding author upon request.

\section{Conflicts of Interest}

The authors declare that they have no conflicts of interest.

\section{Acknowledgments}

The authors would like to thank the reviewers and associate editor for careful reading and helpful comments on the revision of the paper. The authors are also very grateful for the work of Dr. Xueli Zhan.

\section{References}

[1] J. Zhang, Financial Analysis of Modern Enterprises, Economic management press, Beijing, 1997.

[2] D. Xu, Credit Economy: Drive the Market to Maturity, Guangming daily theory edition, Beijing, 2015.

[3] D. Xu, "Suggestions on innovation development of commercial credit system," Macroeconomic Management, vol. 2, pp. 62-66, 2017.

[4] W. Zhang, "On the risk and pricing of asset securitization of accounts receivable in entity enterprises," Finance Research, vol. 347, no. 5, pp. 194-206, 2009.

[5] Y. He, H. Chen, and B. Zeng, "Pricing analysis of accounts receivable financing," Finance and Economics, vol. 09, pp. 14-16, 2010.

[6] A. Szpulak, "Efficiency of the receivables rotation ratio as a measure of the accounts receivable settlement period," Operations Research \& Decisions, vol. 3-4, pp. 129-142, 2010.

[7] J. Zhan, F. Zhang, and J. Zhao, "Research on the joint decisionmaking of supply chain receivable financing and commercial credit," Journal of Systems Engineering, vol. 29, no. 3, pp. 384-393, 2014.

[8] S. Wilkens and N. Bethke, "Contingent convertible ("CoCo") bonds: a first empirical assessment of selected pricing models," Financial Analysts Journal, vol. 70, no. 2, pp. 59-77, 2014.

[9] Z. Wang, Y. Sun, X. Zhang, Y. Duan, and X. Wang, "Investigation on the management of working capital in Chinese listed companies: 2013," Accounting Research, vol. 12, pp. 72-78, 2014.

[10] H. Zhou, G. Li, W. Lin, and Y. Wang, "Analysis and development of credit risk pricing model for corporate bonds," Journal of Management Science, vol. 18, no. 8, pp. 21-30, 2015.

[11] J. Chen, Y. Tao, H. Wang, and T. Chen, "Big data based fraud risk management at Alibaba," The Journal of Finance and Data Science, vol. 1, no. 1, pp. 1-10, 2015.

[12] B. Bahadir and N. Valev, "Catching up or drifting apart: convergence of household and business credit in Europe," 
International Review of Economics and Finance, vol. 47, pp. 101-114, 2017.

[13] M. Gubareva and M. R. Borges, "Rethinking economic capital management through the integrated derivative-based treatment of interest rate and credit risk," Annals of Operations Research, vol. 266, no. 1-2, pp. 71-100, 2018.

[14] L. Jia, G. Xue, Y. Fu, and L. Xu, "Factors affecting consumers' acceptance of e-commerce consumer credit service," International Journal of Information Management, vol. 40, pp. 103$110,2018$.

[15] D. Xu and J. Ma, "Research on management of credit assets in accounts receivable of enterprises," Macroeconomics, vol. 230, no. $1,2018$.

[16] D. Xu and J. Ma, "Enterprises accounts receivable system based on BEST pricing model and block chain technology," Journal of Tianjin University: Science and Technology, vol. 51, no. 4, pp. 433-441, 2018.

[17] D. Xu and J. Ma, "Structuring China business credit management system and relevant characteristic variables base on tree model," International Journal of Information Systems and Supply Chain Management (IJISSCM), vol. 12, no. 2, 2018.

[18] R. Ma, W. Zhang, and Y. Bai, "Improvement of dynamic default probability KMV model for Chinese listed companies," Systems engineering, vol. 32, no. 11, pp. 28-36, 2014.

[19] X. Sun and X. Liu, "The credit risk measurement of bank asset securitization based on the modified KMV model," Journal of Qingdao University, vol. 29, no. 1, pp. 118-122, 2016.

[20] X. Zeng, "A new method on measurement of marketizationunder the view of global trade," Finance \& Trade Economics, vol. $8,2003$.

[21] J. Wu, Internal Rating Theory, Methods and Practice, China Financial Press, Beijing, 2006.

[22] X. Pu and J. Han, Enterprises Financial Risk Warning \& Themeis International New Technology, China Commerce and Trade Press, Beijing, 2011. 


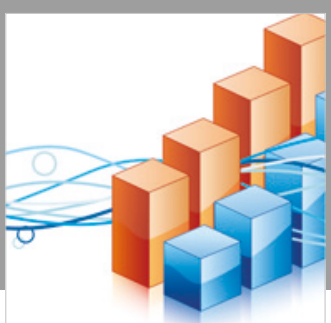

Advances in

Operations Research

\section{-n-m}
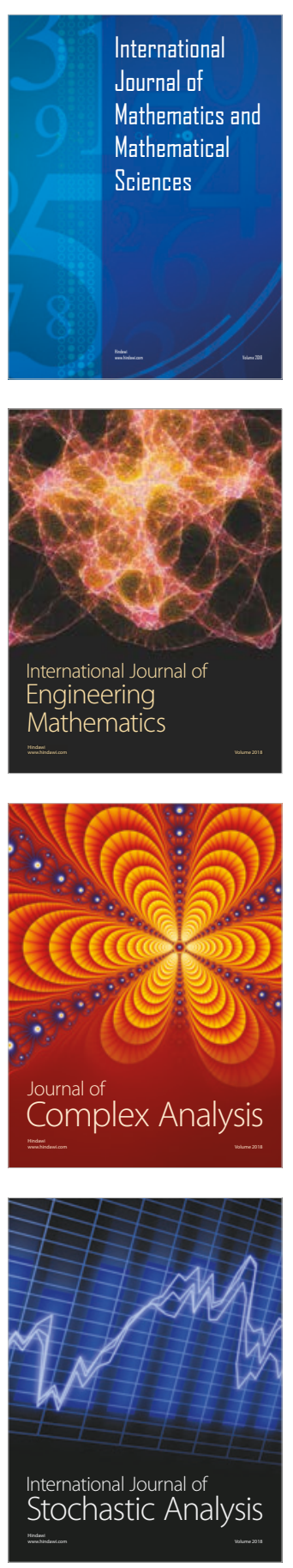
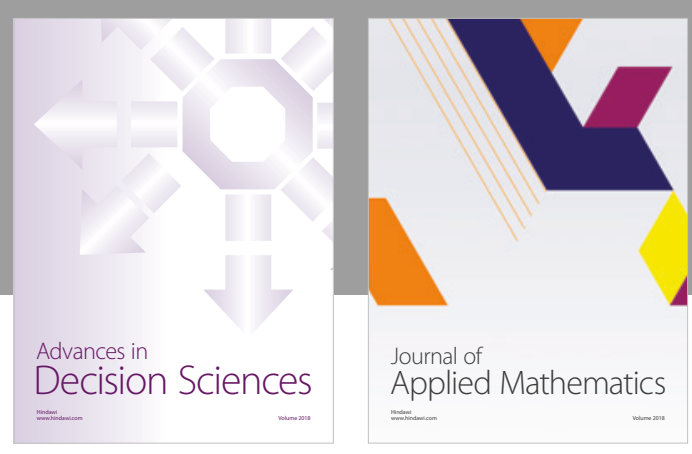

Journal of

Applied Mathematics
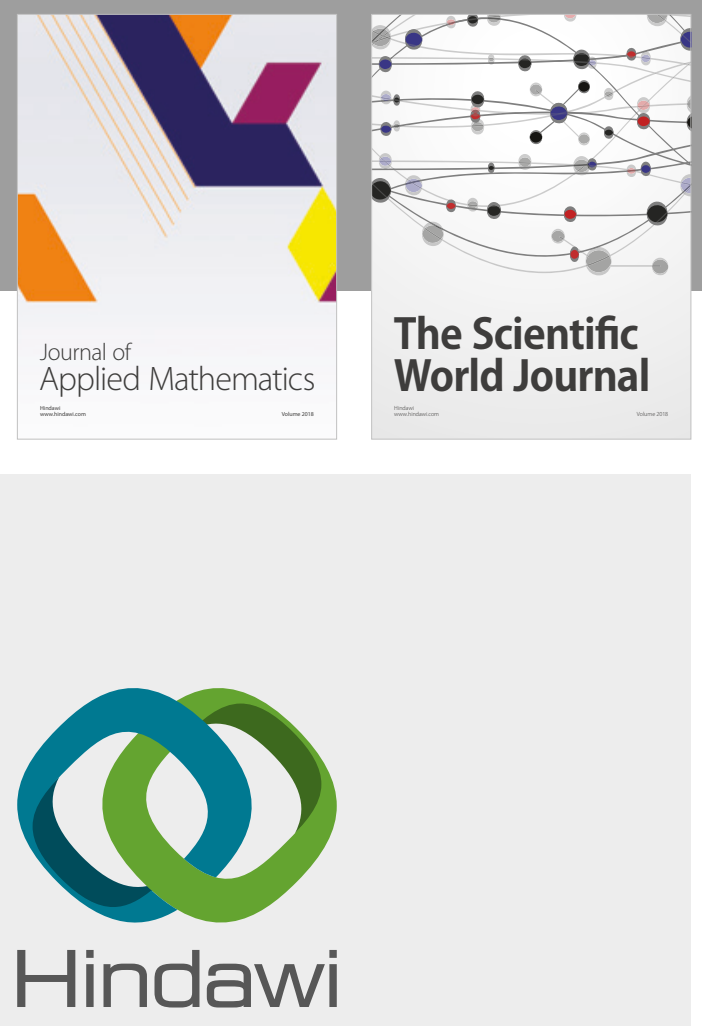

Submit your manuscripts at

www.hindawi.com

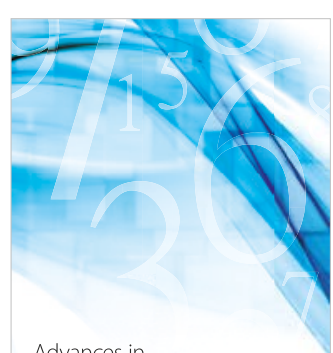

Advances in
Numerical Analysis
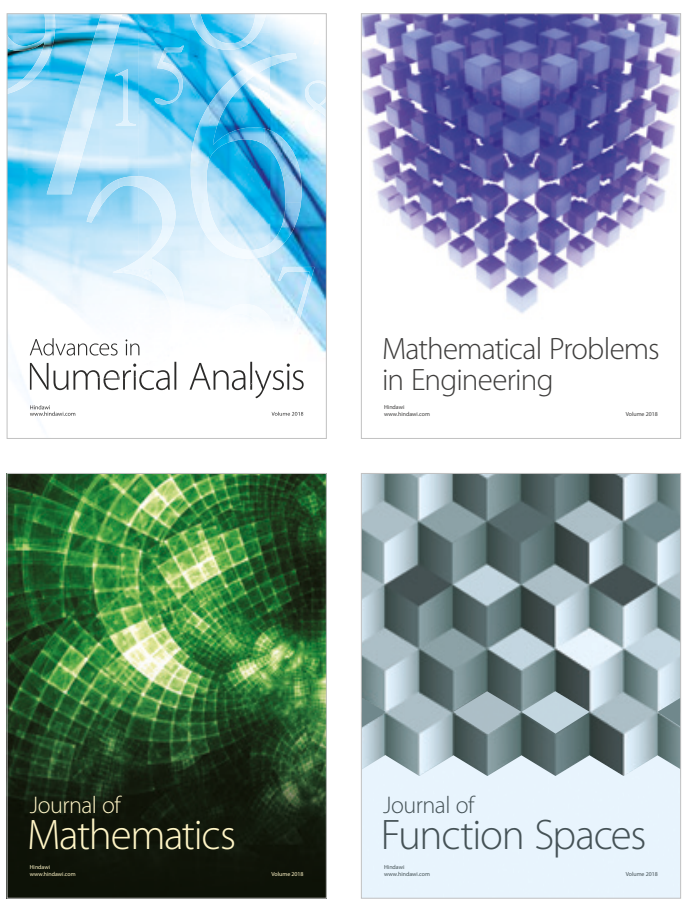

Mathematical Problems in Engineering

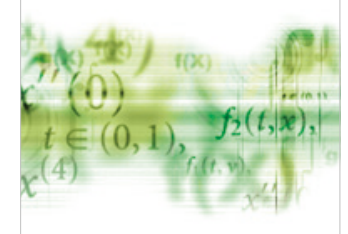

International Journal of

Differential Equations

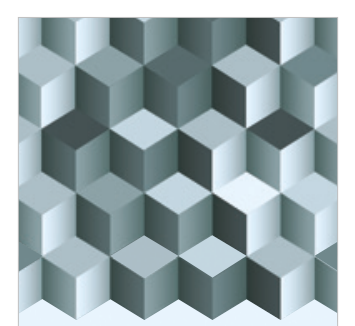

Journal of

Function Spaces
The Scientific

World Journal

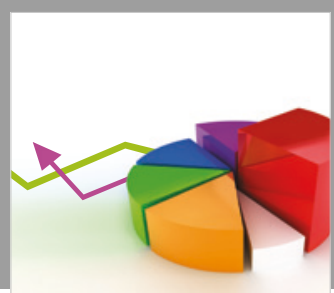

Journal of

Probability and Statistics
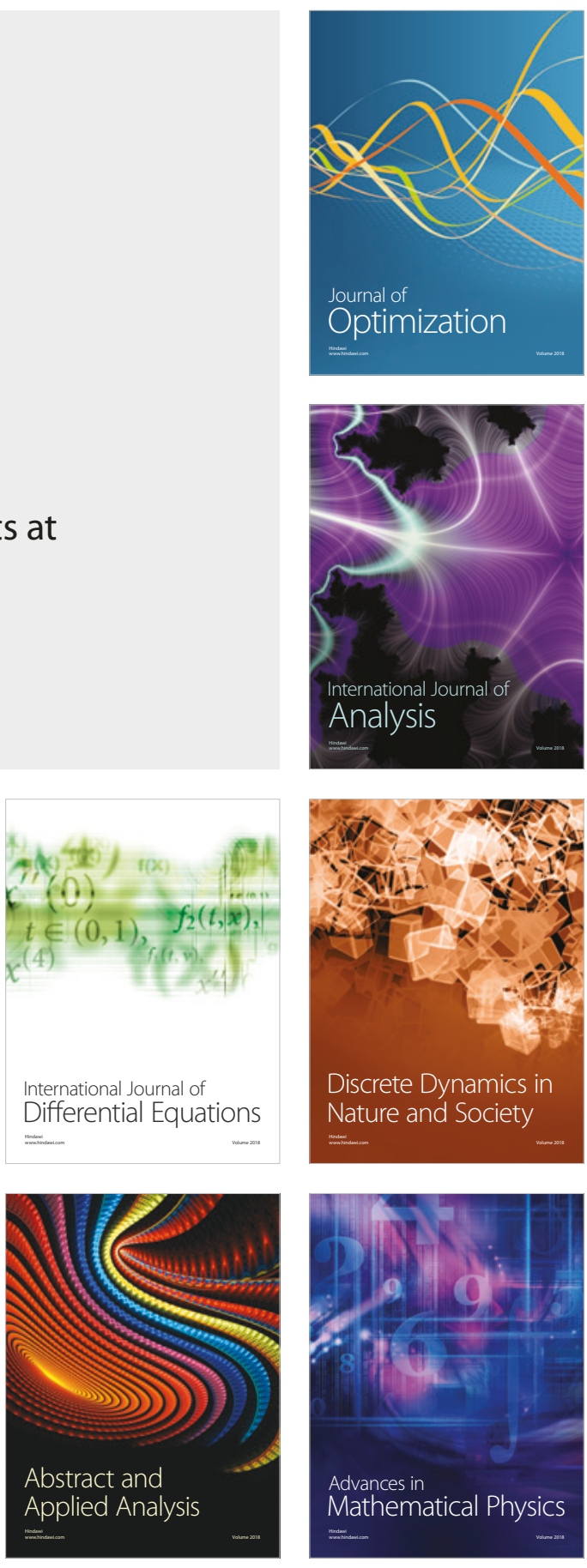